\title{
清掃工場の立地特性に関する調査研究 \\ A RESEARCH ON LOCATIVE CHARACTERISTICS OF INCINERATION PLANTS
}

\author{
大窪 健 之*, 田中俊 樹**, 小林 正美*** \\ Takeyuki OHKUBO, Toshiki TANAKA and Masami KOBAYASHI
}

\begin{abstract}
An incineration plant is one of the most important and indispensable infrastructures to our urban activities. The historical and nation-wide research on sites of incineration plants were made to find the physical and social background of locations. Most of large plants in Japan are located on the urban fringes; river-side, sea-side, mountain-side, administrative-side and social consciousness-side. The result of this research has shown that the tendencies of site dicision was not only depend on the physical and technical backgrounds.
\end{abstract}

Keywords: Infrastructures, Incineration Plant, City Planning, Characteristic of Location 都市基盤施設, 清掃工場, 都市計画, 立地特性

1.はじめに

\section{(1) 研究の背固と目的}

都市生活を底辺で支える都市基盤施設の中でも「清掃工場」と現在 総称される一般廃棄物焼却処理施設は、過㮃な消費活動を続ける現代 社会に扔いては事実上不可欠な施設になって㧍り、日本に約 3 千ある 市町村に対して現在約 2 千の施設が存在し、稼働している。 本研究では、清掃工場の立地環境を対象として、東西都市圈を代表 する 4 都市での「歴史的な変遷」と、近年の「全国的な状況」のそれ ぞれについて整理・分析を行い、施設の立地特性について実証的に明 らかにすることを目的とする。

特に現代では、清掃工場の設置場所の決定システムは、都市計画決 定などを通じて、行政と市民双方のいわば社会的な考え方が反映され る構造となっていることから、本調查を通じて、廃棄物処理に対する 社会的な考え方の、立地環境への表象状況についても考察を行う。

\section{(2) 研究の位置つけけ}

清掃工場の配置問題に関する既往研究には、コミの搬送システムの 提案を通じて清掃工場の合理的な配置を論じた研究"やや、廃棄物の排 出量と収集システムの実態調查からシステムの検証を行った研究 ${ }^{2}$ が
例として挙げられるが、多くは物理的な処理効率の向上を目的とした 技術的研究であり、施設の立地特性を都市計画的観点から実証的に分 析しようとするものではない。一方、清掃工場以外で一般に迷惑施設 と呼ばれる施設を対象とした研究例には、下水処理場を対象にコミュ ニティ施設との複合化と迷惑意識の関係を調べた研究 ${ }^{3 i}$ や火葬場の 建設計画の問題を対象とした一連の研究4! がある。

本研究によって、清掃工場の立地特性を時代性・地域性の两面から 明らかにすることは、環境問題解決の根本に関わるであろう廃臬物問 題に対する社会思想の実状を把握する上でも必要な作業といえる。

\section{（3）研究の対象と方法}

研究対象としては、立地特性の時間的な変遷調査に関して、古くか ら清掃工場が発達してきた歴史的経緯を持つ(1) 大阪市を含めた、京 都市、神戸市という関西圈の 3 大都市と、対する関東圈の大都市であ る東京都の23区部における、過去から1996年現在までに建設された全 84事例を調查対象とした。

一方全国に扔ける近年の同時代的な調查に関しては、建設に際して 多くの自治体で環境影響評価報告の手続き義務が課される基準となっ ている、1 日のごみ焼却処理量 $200 \mathrm{t}$ 以上の大規模な施設のうち、近
$*$ 京都大学大学院工学研究科環境地球工学專攻 助手.工博

** 京都大学大学院工学研究科環境地球工学専攻 *** 京都大学大学院工学研究科環境地球工学尃攻 教授. 工博
Research Assoc., Department of Global Environment Engineering, Kyoto University, Dr. Eng.

Department of Global Environment Engineering, Kyoto University

Prof., Department of Global Environment Engineering, Kyoto University, Dr. Eng. 
年約10年間（1985 1996年）に建設・改築された、東西 4 都市も含む 全国の清掃工場すべてに該当する122事例 (2) を調查対象とした。

調查の方法について、時間的な変遷の調査に関しては、過去の事例 も含めて所在地を追跡調查し ${ }^{(3)}$ 、国土地理院発行の 2 万 5 千分の 1 （明治期については 2 万分の 1) 地形図を基に、施設が建設された時 期に最も発行年の近い地図上で場所を特定した上で（次ページの地図 - 1 ４ は、参考のため1998年現在の地形図上にすべての事例をプ ロットした地図である)、すでに現存しない清掃工場については地図 上から周辺環境を読みとり、現存する36事例については現地調查及び 清掃事業体担当者へのヒアリングで補足を行うことで配置環境を把握 することとした。各時代のごみの収集方法と輸送技術については、各 清掃事業体が年度ごとに発行している「清掃事業概要」等、過去の刊 行物と文献史料を照らして整理を行った。

近年の大規模施設に関する全国の同時代的な調査に関しては、対象 となる122工場の清掃事業体発行の広報用資料（パンフレット等）を 収集し、地形図および土地利用図を基に場所を特定して、地図情報お よび電話によるヒアリングから周辺環境を読みとる形式で行った。

\section{2. 立地特性の時代推移}

東京都区部および大阪市・京都市・神戸市の、過去から1996年現在 に至るまでに建設された清掃工場のうち、過去の敷地上に建て替えら れた事例と区別する形で、新規の敷地に新築された65事例を中心に、 物理的・社会的な立地特性の時間的変遷について分析を行った。

併せて背景にあるごみの収集・輸送技術の推移について調査結果を 記述し、立地特性の推移を概説する。

（1）市街地近郊立地期（1900年～1955年頃）

水面との関係について見ると、1955年頃までは $90 \%$ 以上の施設が水 路や海面、河川敷に隣接して建設されており、水面と密接に関わりを 持っており、これ以降は $2 \mathrm{~km}$ 以上離れた場所にも設置され始めている いることがわかる。（図ー1）

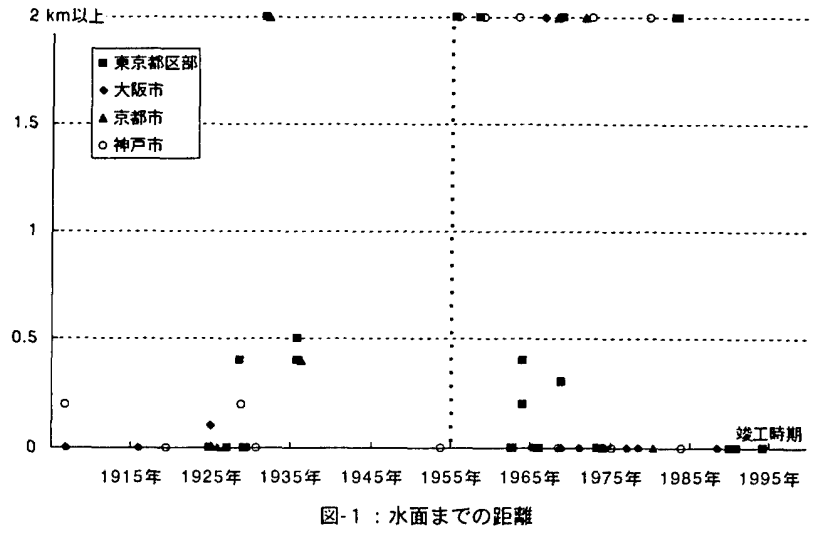

地図上ハッチで示される市街地との関係については、やはり1955年 頃までは市街地内部に設置される場合や、市街地から500m以内に近 接する市街地近郊に設置される例が中心となっていた。（図ー2）

この背景には、当時各都市内の物資輸送の手段として水運が主流で あったため、ごみの大量輸送にも運溥が欠かせなかったことと、ごみ の収集作業が手車（肩引車）や牛駐車により行われていたため、一度
に運搬できる量と距離とが限られており、中継施設や焼却処理施設な どのごみ集積施設は、水面および市街地になるべく近い場所に設置す る必要があったという事情がある。

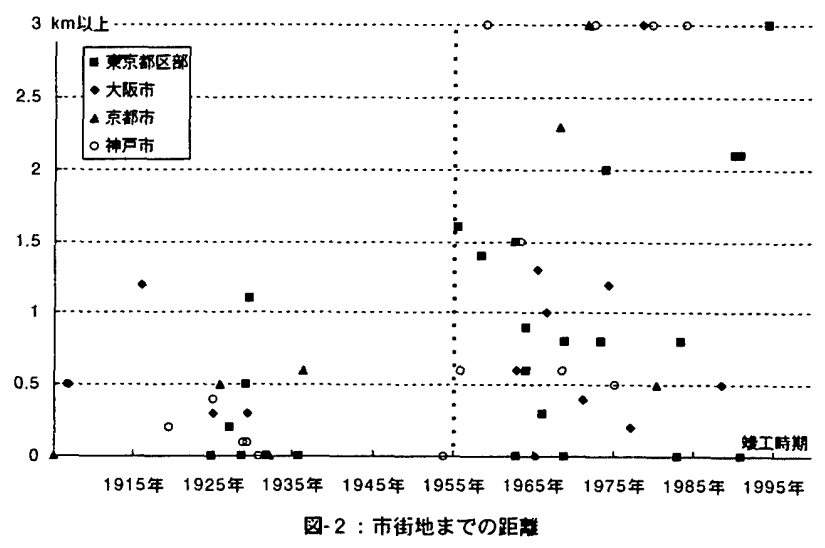

この時期には、主に収集・運搬の技術的な理由が、立地環境の決定 に大きく影響していたと考えられる。

（2）郊外立地期（第।期）（1955年～1965年頃）

第 2 次世界大戦を経た高度経済成長を時代背景として、陸上の道路 網が整備され、自動車交通が一般化し始めると、ごみの収集運搬作業 も機械化が進み始める。東京都では1951年に小型トレーラーによる自 動車作業が開始され、1961年には自動車の全面的な導入により機械化 が完了。大阪市では1951年に小型三輪自動車が試験的に導入されて、 1969年には全ての収集車のパッカー化が完了している。京都市では自 動車の試験導入が1923年頃で他都市よりも早いが、清掃事業の機械化 としてパッカー車が本格導入されたのは同様に1962年であった。神戸 市では1959年には収集作業にパッカー車が導入されている。

これにより直接的な長距離輸送が可能になると、焼却処理施設の立 地条件として、道路に接続していること以外は先の時代にあったよう な技術的・物理的な制約条件が弱まる結果となる。

しかし実際の立地環境の傾向を見ると、1955年頃からは逆に市街地 から離れた場所にも数多く建てられ始めており（図一2）、周辺の土 地利用状況も農地や工業地などが主流となって、特に域内に山地をも つ都市では、道路を敷設して山中にも立地するようになる。

また行政区域境界線（海岸線を含む）との関係では、この時期以降 は $500 \mathrm{~m}$ 以内の距離で境界線に近接する施設が全体の約半数を占める ようになる。(図一3，4）

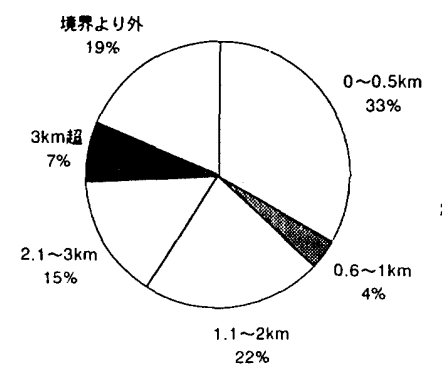

図-3：行政境界線までの距雖 (1955年以前)

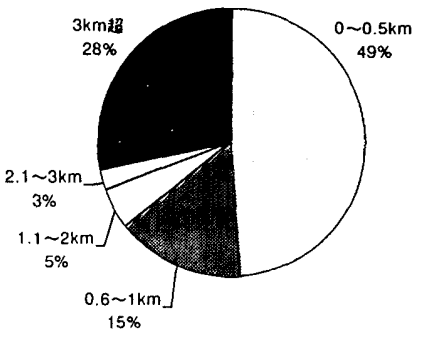

図-4:行政境界線までの距 (1955年以降)
この時期、本来であれば物理的制約から自由になった分だけ、施設 の配置計画に関して、ごみの収集面でより効率の良い機能的な形態が 


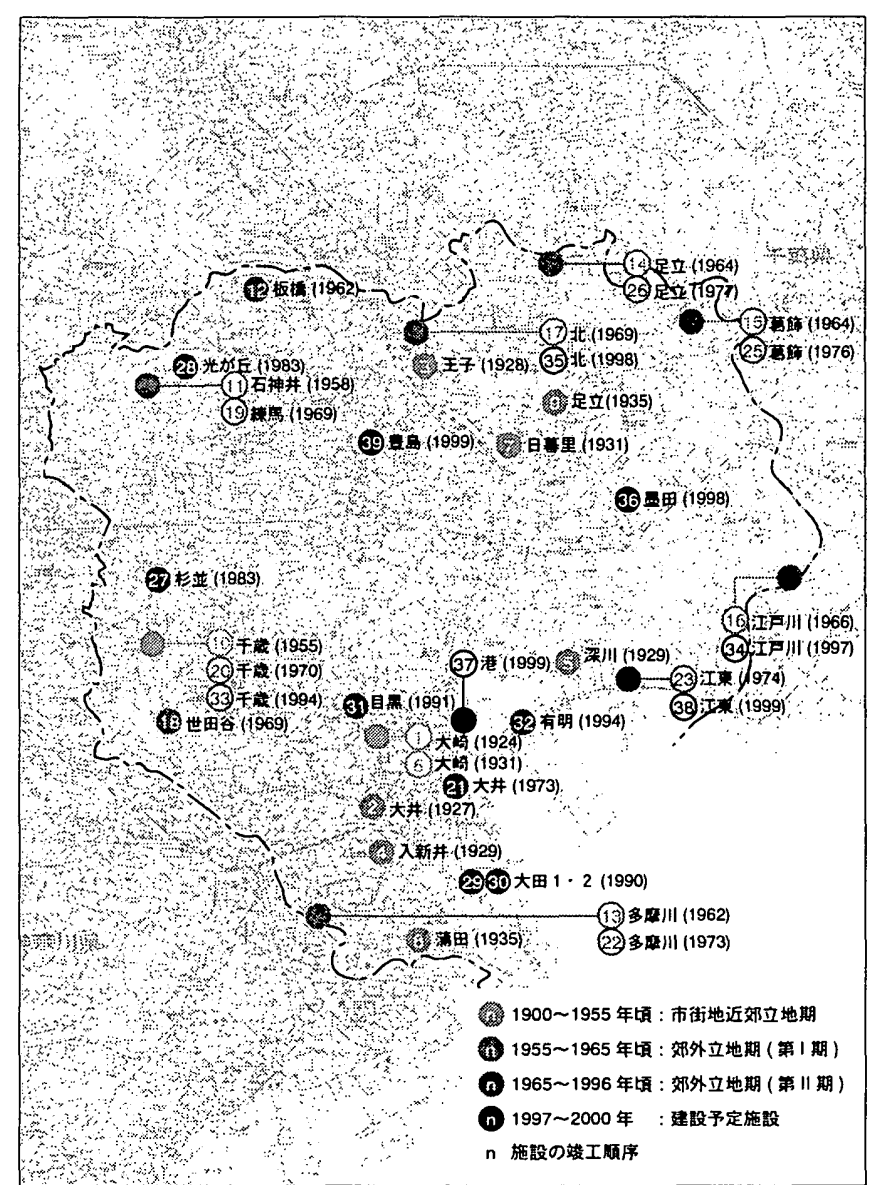

地图 -1 : 施設配置の变遥・東京都区部 $(\mathrm{scale}=1 / 40$ 万）

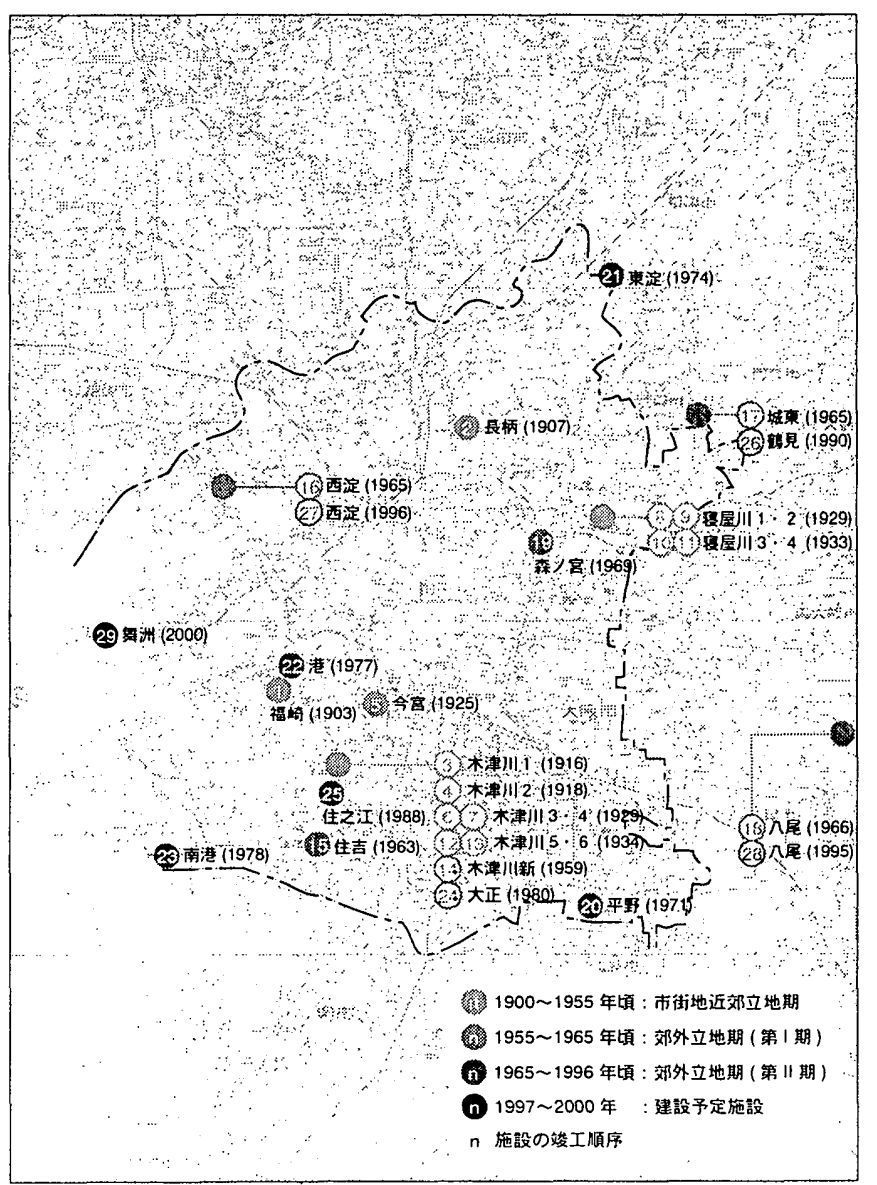

地図 $-2:$ 施設配曋の变遮・大阪市 $($ scale $=1 / 40$ 万）

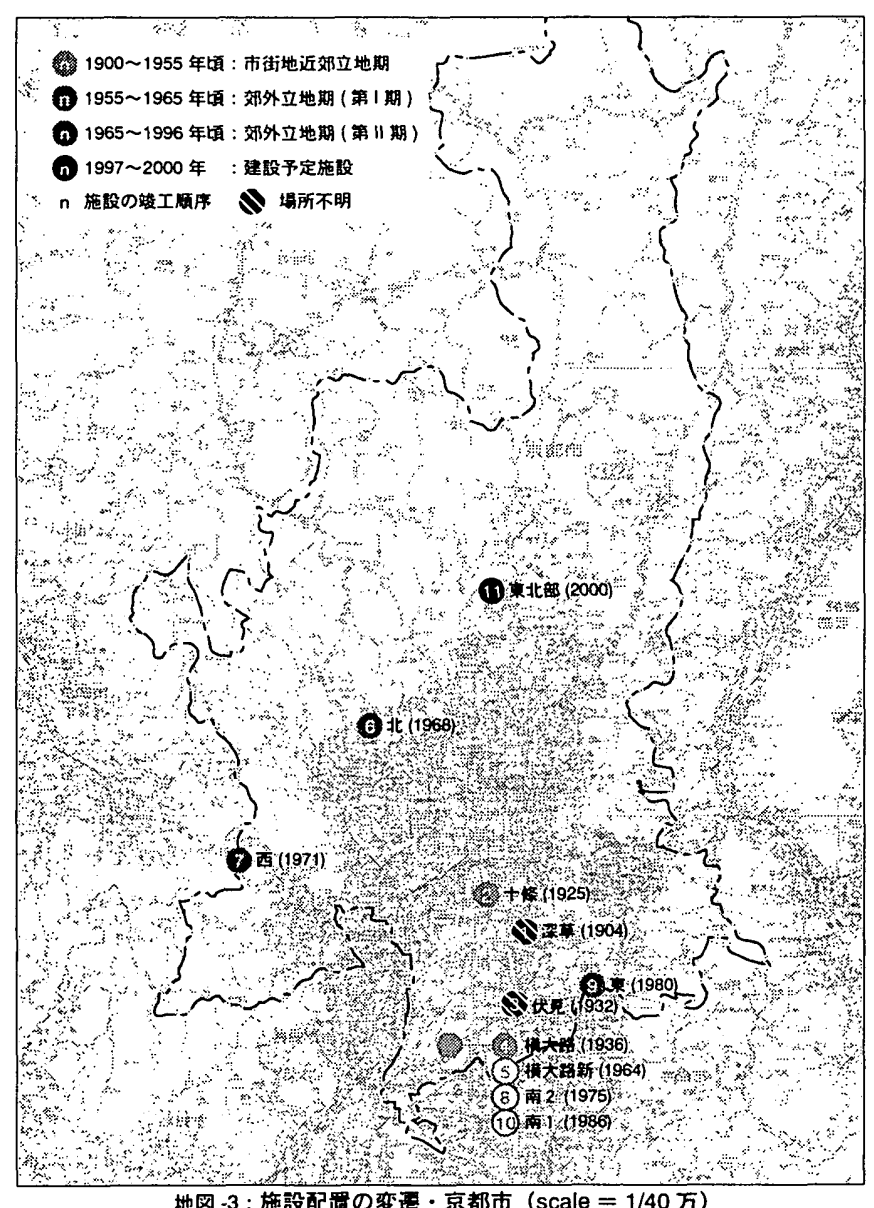

地図 -3 : 施設配置の变要・京都市 $($ scale $=1 / 40$ 万 $)$

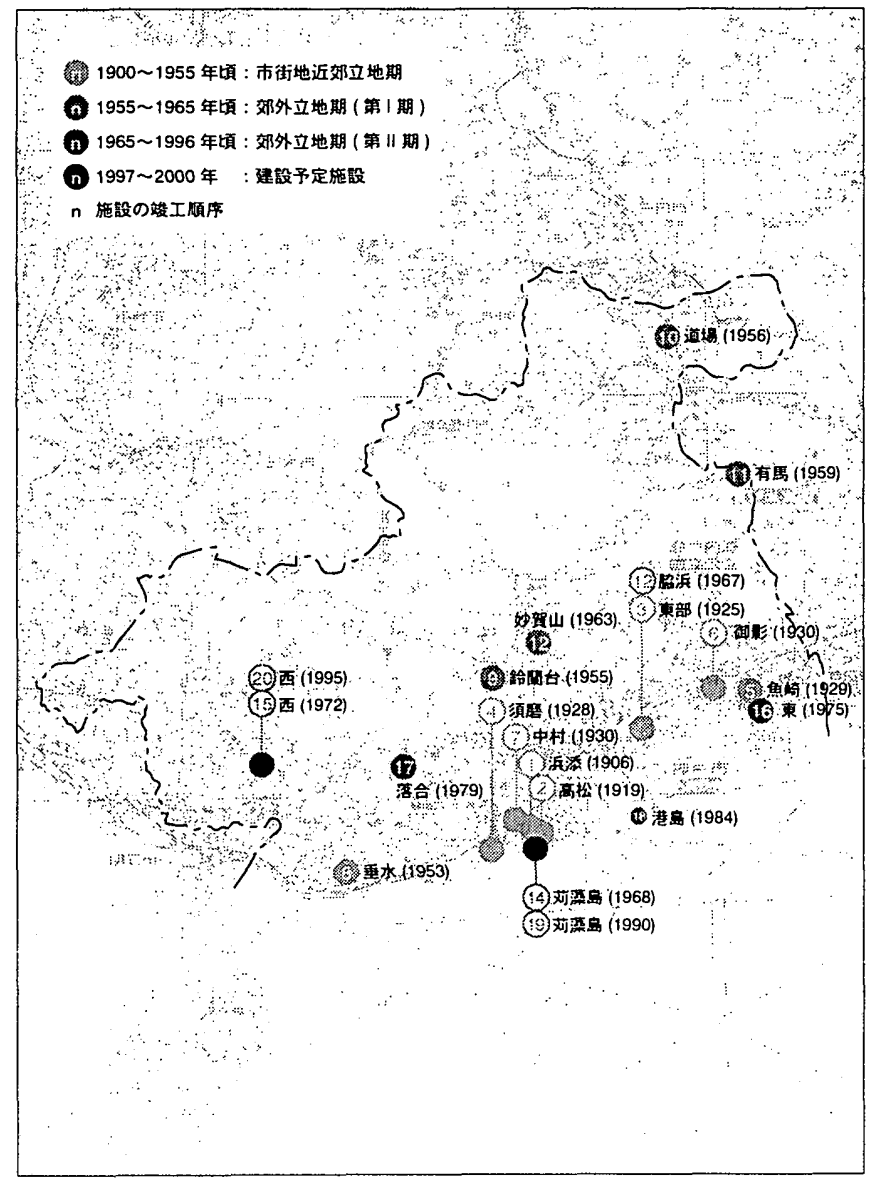

地图 -4 : 施設配置の变透・神戸市 $($ scale $=1 / 44$ 万） 
可能となるはずであるが、実際にはこれとは逆に、施設を地域から外 に押し出そうとする煩向が現れ始めている。

（3）郊外立地期（第 11 期）（1965年～）

この時期の施設の配置環境の特徵としては、同じ敷地への建て替え が行われるようになったこと（図ー5）と、施設が埋立地に立地し始 めたこと（図ー6）が挙げられる。
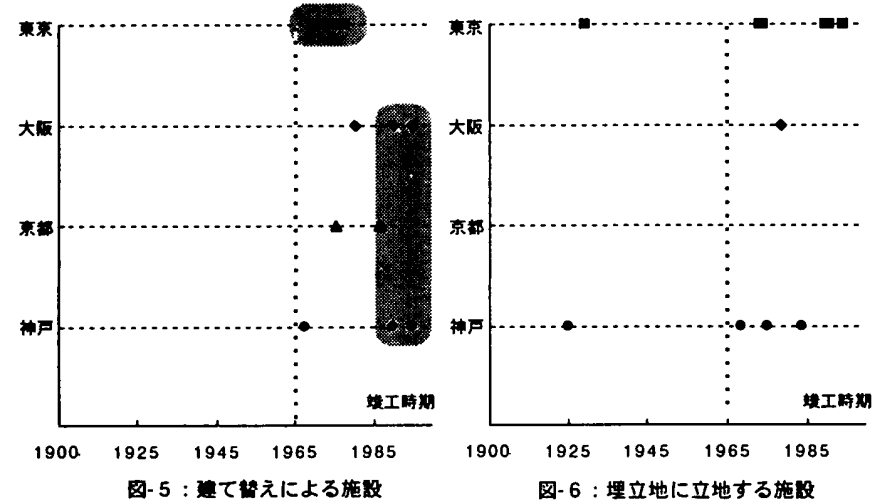

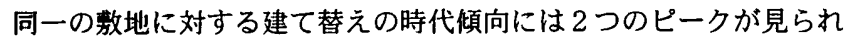
るが、1970年代のピークについては、1960年代を通じて開発・標準化 された連経式炉を、既存のバッチ式炉施設の性能向上の目的でこの時 期に導入し始めた東京都区部の 6 施設を反映しており、1990年代のピ 一クについては、1960年代に一斉に建設された連続式炉施設が、20〜 30年経って更新の時期に差し掛かった関西の 4 施設を反映している。

連続式炉が導入されて以降は、一定期間稼働した後には炉の全体を 更新するために建築部分も含めて取り壊すことが一般的となっており (ごく近年では建築部分を残して妒のみを更新できるような設計 ${ }^{(4)}$ も試みられている）、今後は施設の機能を維持する上でも、新規の土 地が得にくくなっている社会的状況からも、同じ敷地上で定期的に建 て替えが行われるケースが多くなると考えられる。

また、東京都区内では1973年の大井清掃工場、大阪市では1977年の 港工場、神戸市では1968年の刚藻島クリーンセンターの設置以降、 1965年以降に竣工した全44施設中 9 施設（20\%）が埋立地に建設され る形で再び水面を目指すようになる。この時期、埋立地への建設技術 が確立されたことが一つの要因となったと考えられる。

これらの背景には、新規の敷地の確保が困難になり、焼却炉の更新 を必要とする時期に差し掛かったことや、多くの都市で市街地内部が 飽和状態に近づいたために、輸送コストの面から見ても理想的な都心 の近辺に、新規の郊外地を求めて 埋立地への開発が積極的に行われ てきたことが挙げられる。

一方1970年に第64回臨時国会 （通称は公害国会）が開かれるな ぞ、1965年頃以降には、公害問題 がクローズアップされ始め、施設 の設置に伴う周辺住民の負担を補 償するという考え方で、57\%の施 設で設置に際して地域還元施設が

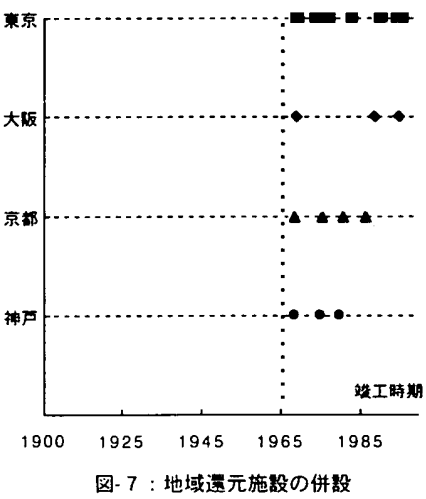
建設されている（図一7）。

\section{3、近年における全国的な立地特性}

ついで、近年の全国的な煩向を把握するために、1985年以降1996年 までに建設された、全国の大規模な清掃工場122事例（清播事業体 数 : 104）の物理的・社会的な環境について傾向分析を行った。

3-1. 土地利用に対する傾向

(1) 都市計画の地域地区区分

各清掃工場の敷地に関して、まず都市計画法により規定される地域 地区区分について調查を行い、その全国比率を調査した。（図一-8）

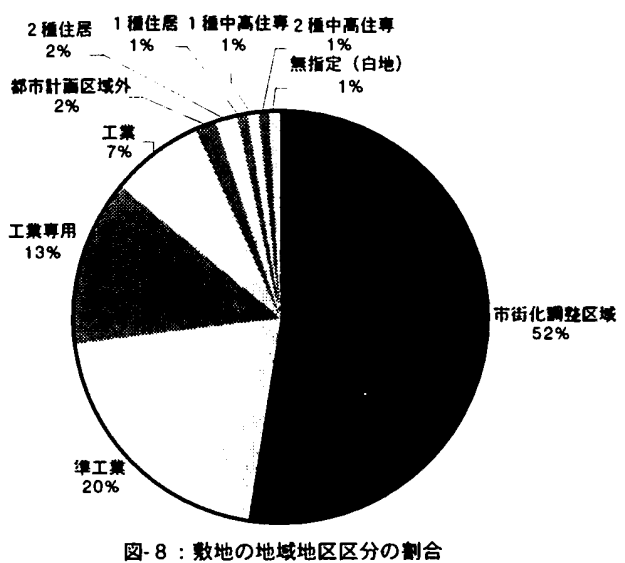

清掃工場のプラントとしての機能面から、工業系の用途地域区分に 立地する割合が多い（合計40\%）ことは妥当だとしても、実際には、 都市施設であるにもかかわらず、都市計画法第 7 条 3 項で「市街化を 抑制すべき区域」と定められている「市街化調整区域」に建設されて いる例が、全体の半数以上（52\%）を占めている。

\section{（2）数地の土地利用区分}

一方、実際の状況により近い地理的な土地利用区分で見た場合に は、各清掃工場の立地する教地がどの項目に属しているのかを把握す るため、対象施設が立地する前の1982年〜1983年に調查された最新の 国土地理院による「20万分の 1 土地利用図」をもとに調查を行った。 敷地に該当する場所を地図上で特定したうえで、そこに示される土地 利用について、14項目 ‘)に分けて集計する方法を採用した。各土地 利用区分に該当する施設数の、全施設数（122施設）に対する割合を 示す (図-9)。合計で54\%と半数以上の施設が農林地に建設されて いる一方、清掃工場が公共施設であることから標準的な立地区分と考 えられる、公共公益用地に建設されている例は17\%で、順位で見ても 田、林、工業地に次ぐ位置にとどまっている。

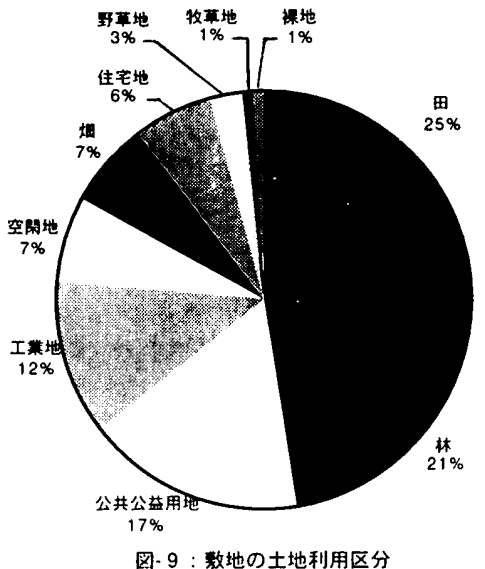

园-9：数地の土地利用区分 


\section{（3）周辺の土地利用状況}

さらに、清掃工場を取り巻く周辺地域の、一般的な土地利用状況に ついて把握するために、施設周辺における各種土地利用区分の面積比 について、全国的な平均値を求める。調查手順としては、土地利用図 をもとに、施設を取り巻く半径 $1 \mathrm{~km}$ の円内を「周辺」とみなして88個

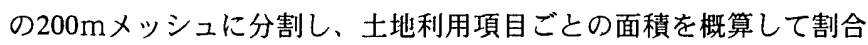
を算出した。

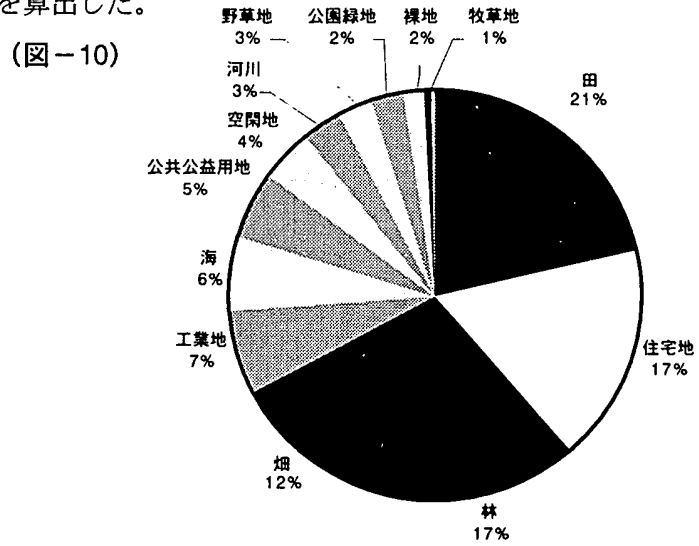

図-10: 数地周边の平均的な土地利用割合

施設周辺の全国平均面積比率で見ても、やはり農林地の占める割合 は50\%と半分の面積を占めている。住宅地に関しては、（2）項の結 果では全体の $5 \%$ 施設のみが住宅地内に立地していたのに対して、 周辺土地利用の全国平均面積比率では17\%を占めている。清掃工場に 隣接する例は少ないものの、周辺の $1 \mathrm{~km}$ 圈内にはある程度の割合で住 宅が存在していることを示している。

\section{3-2. 地理的条件に対する傾向}

清掃工場の立地する環境について、水面や山地といった地理的な条 件との関係性について全国的な傾向を把握する。

\section{(1) 水面との関係}

2 章で明らかとなった、歴史的に清掃工場の立地に深い関わりを 持っていた水面との関係について、近年の大規模施設における傾向を 把握するため、 $500 \mathrm{~m}$ 以内で水面に近接するかどうか、近接する場合 には水面の種類について、地形図をもとに調査・集計を行った。

各条件に該当する施設数の割合を（図一11）に示す。

水面に $500 \mathrm{~m}$ 以内で近接する施設数を全体に対する割合で見ると、 合計 $59 \%$ の施設が水面に近接して建設さ扎ていた。

近年では、1955年以前の状況とは異なり、清掃工場までのごみの収 集運搬に水上運漕を利用している清掃事業体はほとんどなく、埋立地 に立地する一部の施設が暁却灰の積み出しのために船積み装置を備え て、海面上の埋立地へ直接船で連搬しているにとどまる。

水面に関倸して立地する近年の傾向として、特に全体の $31 \%$ の事例 が河川敷付近に立地することについては、汇濫の危険性などから歴史 的にも人が住み難かった場所であり、設置に際しては土地収用の問題 が発生しにくいため、行政側として設固しやすいという背景があると 考えられる。

\section{（2）山地との関係}

施設の敷地と山地との関倸について、近年の大規模事例における一 般的な傾向を把握するため、施設の糤地が山中に位置するか、または 500m以内の距離で山地に近接するかどうかについて、地形図をもと に調査・集計を行った。

条件に該当する施設数の全数に対する比率を（図ー12）に示す。
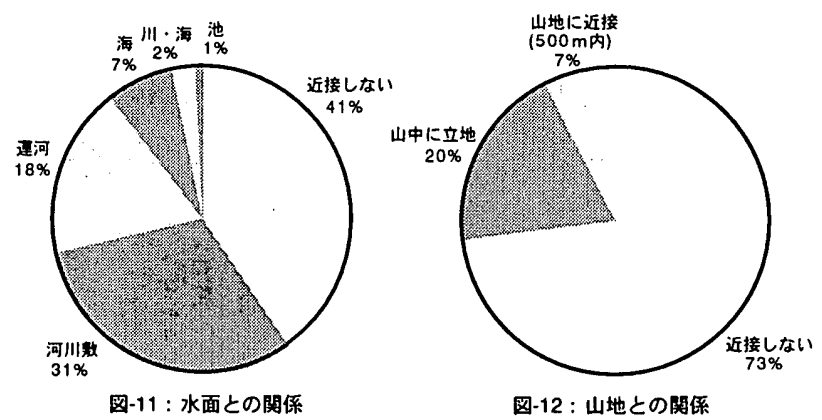

山地との関連では、山中に立地するものが20\%、山地に近接するも のが7\%あり、合計 $27 \% の$ 施設が山地に関連して建設されている。

結果全体の $1 / 4$ 程度の施設が、あえて平地ではない山地に関係す る場所に設置される背景には、山地には一般に民家が少なく、樹木な どによって周辺市街地から見通しの悪い場所になりやすいため、設置 にあたって比較的反発を受けにくい傾向があると考えられる。

\section{3-3．各種境界線に対する傾向}

ある条件を満たす領域に対してその外縁に該当する「境界線」と、 清掃工場の敷地との関係について全国的な傾向を把握する。

\section{（1）DID境界線までの距離}

総務庁統計局により設定（1995年版）されている人口集中地区 （DID）の境界線を、人口の集中する地域の外縁とみなし、各施設か ら最寄りのDID境界線までの距離を測定することで、施設の立地環境 が人口の集中する地区の外縁とどのような関係にあるのかを明らかに する。DID境界線までの距離帯別の施設数を（図ー13）に示す。

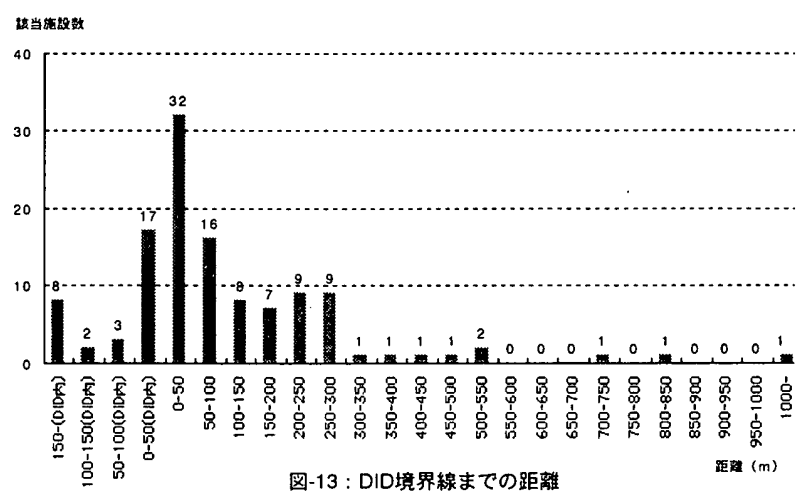

DID境界線から内外 $100 \mathrm{~m}$ 範囲に設置されている施設数について 集計すると全体の半数以上（56\%）を占めており、グラフからもDID 境界線付近に大きく偏って分布している。この結果からは、施設は人 口の集中している地域に対して、その外縁付近に立地する一般的傾向 があることがわかる。

\section{（2）行政区域境界線までの距離}

清掃事業体の行政区域境界線を一つの地域的な外縁部とみなし、各 施設から、施設の属する自治体（市町村）の行政区域境界線（複数の 自治体で広域清掃事業を行っている場合は、あわせて 1 つの清掃事業 体と見なした）までの最短距離を地形図上で測定した。施設の立地環 境が地域の外縁部とどのような関係にあるのかを明らかにする。 
境界線までの距離帯ごとに、該当する施設数を示す。（図一14） 行政区域境界線から $500 \mathrm{~m}$ 未满の籍囲に設置 されている施設数のみ で全体のほほ半数（47 \%)を占めており、グ ラフからも境界線に近 接して立地するケース と $3 \mathrm{~km}$ 以上離れるケー スとに大きく偏って分 布する頃向にあること がわかる。

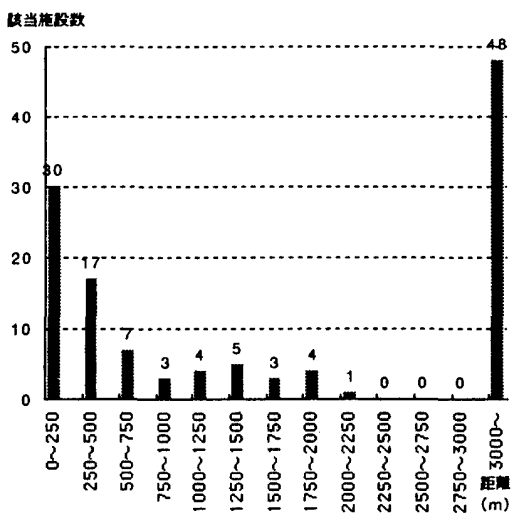

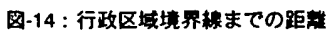

3-4. 各程周辺施設に対する傾向

清捛工場の立地する周辺環境に対して、立地している他の各種都市 施設との関倸性について全国的な傾向を把握する。

(1) 公固施設との関係

施設立地と、市民が自由に利 用することのできる公園施設 （緑地公園・運動公園・都市公 園など）との関係について、近 年の大規模事例における傾向を 把握するため、敷地内に公園施 設を併設しているか、500m以 内で公園施設に近接するかにつ

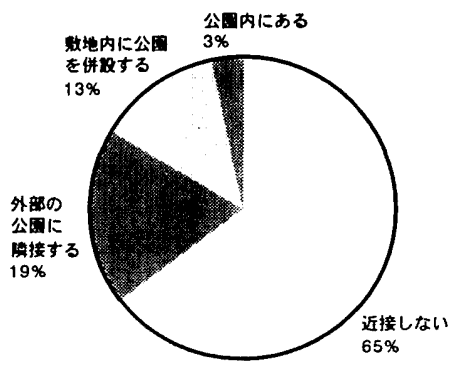

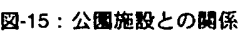

いて、地形図をもとに集計を行った。各条件に該当する施設数の全国 比率を（図一15）に示す。

合計で $35 \%$ の施設が公園に接する形をとつており、特に $13 \%$ の施設 は数地内部に公園を設けている。公園は施設の周辺に対する緩衝地帯 としての役割と、地域に対する一種の地域還元施設としての役割を果 たすものとして設置されていると考えられる。

\section{（2）地域遈元施設の併設}

清挦工場の設置に際して周辺地域に及ぼすマイナスの影響を補僙す る目的で、1965年頃以降に設置され始めた「地域還元施設」の傾向を 把握するため、広報用資料に基づき種別ごとに集計を行った。

付随する公園施設を除いた地域還元施設の種別について見ると、大 きく、余熱利用温水プールや体育館、浴場などの福利厚生施設と、老 人ホームや老人秘いの家などの高齢者を主対象とした高齢者福祉施設 の2つに分けることができる。62例の清掃工場に福利厚生施設が、20 例に高齢者福祉施設が併設されており、全体で見ても 7 割近い67\%の 清揭工場に何らかの地域還元施設が設けられていることとなる。

(3) その他の周辺都市施設

施設に直接関連する上記（1），（2）項の施設を除く、周辺 $1 \mathrm{~km}$ の範囲に立地しているその他の都市施設について、地図上で調査を行 い、種類別に集計を行った。

付近に立地する代表的な都市施設としては，上水・下水・屎尿処理 場（26例）、リサイクルプラザ“”（17例）、火葬場・墓地（12 例）、卸売市場（9例）、最終処分場（5例）が挙げられる。
リサイクルプラザと最終処分場は清掃工場に関連の深い施設である が、上水・下水・屎尿処理場や火葬場・墓地については、清掅工場上 あわせて「代表的な迷惑施設」ら)と見なされていることから、すでに 他の迷惑施設が決定されている場所であれば、新しく清掅工場を建設 する場合でも問題とされくいという社会的傾向があると考えられる。 卸売市場については、建設に際して同様に都市計画決定を行わなけれ ばならない施設であるため、同一の手続きに乗せて場所が決定される など、法規的要因により近接して立地する傾向にあると考えられる。

\section{4. 近年における地域特性別の立地傾向}

次いで、施設の立地する清掃事業体を地域特性ごとに 5 つの型に分 類し、それぞれの地域特性ごとの施設の立地傾向について大まかな分 析を行った。調査対象は 3 章同様に、近年11年間に建設された全国の 大規模清掃工場122例とした。

\section{4-1．清堣事業体の地域特性による分類}

対象施設の立地する清掃事業 体について、可住地面積割合

（総面積から林野面積を差し引 いた面積の総面穔に対する比 率）、DID面積割合（人口集中 地区の面積の総面積に対する比 率）、DID人口割合（人口集中 地区に居住する人口の総人口に 対する比率）の3指標によって 分類した。

可住地面積割合は、度数分布 図（図ー16）により $70 \%$ 近辺 を谷として $100 \%$ 近辺と $50 \%$ 近

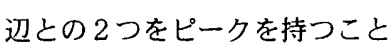
から、0\%〜 70\%未満を可住地 面積割合「低」、70\%以上〜 $100 \%$ 「高」と大分類した。

同様にDID面積割合は、度数 分布図（図－17）により40〜 $80 \%$ 谷として $100 \%$ 近辺と 20 \%近辺の 2 つをピークを持つこ とから、0\% $60 \%$ 未満をDID 面積割合「低」、60\%以上～ $100 \%$ 「高」と大分類した。

DID人口割合については、 $100 \%$ 近辺にピークがあるのみ で度数分布図（図-18）は0\% へ向けて等比級数的に隇少して
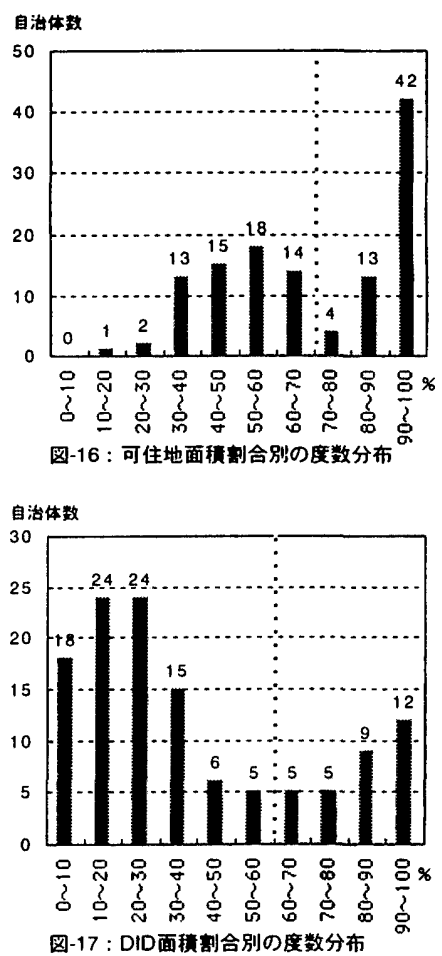

活体数

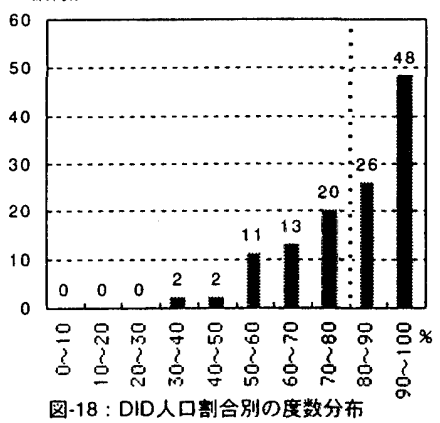

いるため、全体事例数の半数を占める $80 \%$ 以上〜 $100 \%$ 「高」、残 る0\%〜80\%未満を「低」として大まかな分類を行うこととした。

これらの指標をもとに、（表ー1）に示すように、122施設に対応 する清掃事業体（自治体）を地域特性別に区分を行った。 
表中(1)は多くの面樻比 を占める平野部（可住地） 全域にわたって市街化され ている、東京都・大阪市・ 名古屋市など、30の清掃 事業体を含む「平野部都市 型」、(2)は人口の集中し ているコンパクトな市街地

\begin{tabular}{|c|c|c|c|c|c|}
\hline & \multicolumn{2}{|c|}{ 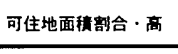 } & \multicolumn{2}{|c|}{ 可住地面種唎合 - 低 } \\
\hline & & \multicolumn{2}{|c|}{ D１Ｄ面措割合 } & \multicolumn{2}{|c|}{ D I D面啭制合 } \\
\hline & & 高 & 低 & 高 & 低 \\
\hline $\begin{array}{l}D \\
1 \\
D\end{array}$ & 高 & $\begin{array}{c}(1) \\
\text { 平野部 } \\
\text { 都市型 }\end{array}$ & $\begin{array}{l}\text { (2) } \\
\text { 都市+ } \\
\text { 足村型 }\end{array}$ & - & 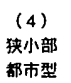 \\
\hline 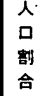 & 低 & - & 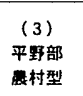 & - & $\begin{array}{c}\text { (5) } \\
\text { 狭小部 } \\
\text { 费村型 }\end{array}$ \\
\hline
\end{tabular}
を持ち、その周囲に人口の集中しない平野部が広がる、新潟市・熊本 市・埼玉県東部清掃組合など、14の清掃事業体を含む「都市+農村 型」、(3)は市街地はあってもコンパクトで人口集中も少なく、平野 部に低密度で人口が分布している、土浦市・宇都宮市・浜松市など、 15の清掃事業体を含む「平野部農村型」と表すことができる。

一方、可住地面積割合の低い平野部が狭く限定された地形では、 (4)は平野部の占める面積割合が少ないにもかかわらず市街地に人口 が集中している、京都市・金沢市・仙台市など、300清掃事業体を 含む「狭小部都市型」、(5)は平野部の占める面積割合が少なく人口 集中も少ない、生駒市・八戸市・郡山市など、33の清掃事業体を含 む「狭小部農村型」と表記することができ、便宜的に各地域特性をこ の分類型で示すものとする。なお、表中の記号「一」で示される型 は、物理的に含まれる要素がほぼ存在しないことを表す。

\section{4-2. 各地域特性ごとの施設の立地傾向}

各地域特性を持つ清掃事業体ごとに、施設がどのような立地環境に 建設される傾向があるのかを把握するため、5つの地域特性ごとに分 析を行った結果について、全国平均に比して明らかに特徵的な結果の 現れた項目について要約的に示す。

(1) 平野部都市型

この型に分類される地域では、公共公益用地に立地する例が $34 \%$ （全国平均：16\%）と最も多く（図ー19）、市街地に設置せざるを 得ない場合に、公共公益用地の形で確保された土地に、他の公益施設 と併せて集中配置する計画手法が採られていることを反映している。 埋立地に立地する事例が30\%（全国平均：15\%）と多いのも、通常の 市街地内には敷地が得にくい地域特性を反映している。

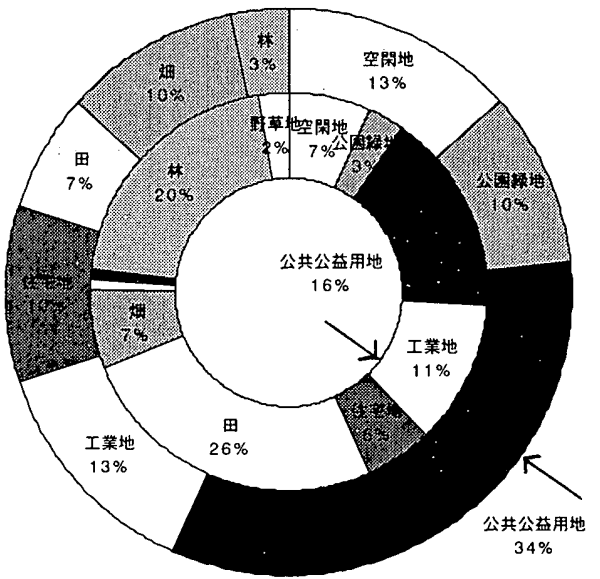

图-19：僌地の土地利用区分割合（内側は全国平均）

（2）都市+農村型

施設の敷地の用途地域については、市街化調整区域が全体の $85 \%$
（全国平均：53\%）を占めており、田に立地する例が全体の65\%（全 国平均：26\%）と最も多い（図一20）。この型の地域の場合、コン パクトな都市部の外に広がる田園地に、多くの施設が立地する傾向に あることを示している。

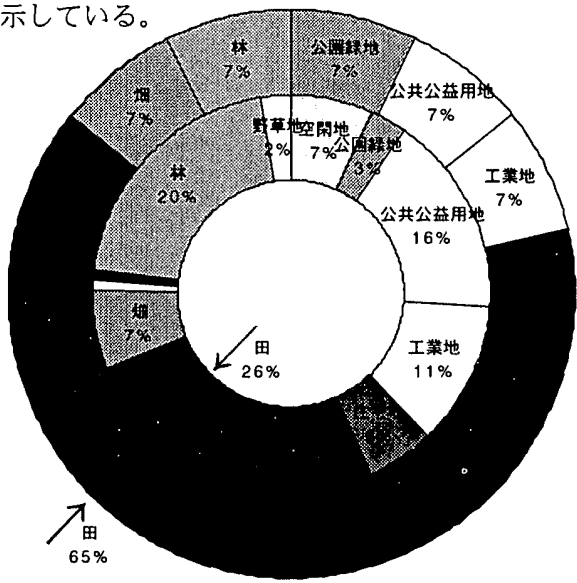

图-20：数地の土地利用区分剖合（内側は全国平均）

\section{（3）平野部農村型}

行政区域境界線までの

距離について、全国平均 よりも距離を取って分布 する傾向が見られる（図 -21）。また敷地の土 地利用区分については、 農林地に立地する例が全 体の $75 \%$ （全国平均 : 53 \%）を占めている。

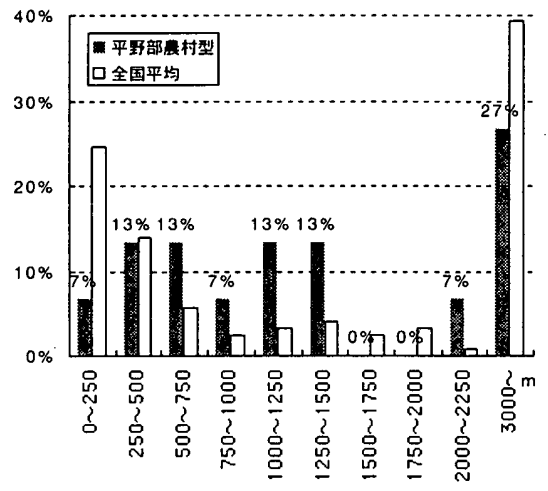

图-21：行政区域境界線までの距離帯別割合

この型のように、全域に渡って人口がまばらに分布し、平野部が多 い場合には、施設を行政区画境界線付近にまで遠ざけて設置する要求 も少なく、広がる農林地の中に建てられていることが示されている。

\section{（4）狭小部都市型}

基本的に「平野部都市型」と同様の立地傾向を示すが、「平野部都 市型」の場合、都市周辺に余地がないためDID内部に全体の60\%（全 国平均：26\%）もの施設が立地するのに対し、「狭小部都市型」の場 合、DID境界線からの距離が $100 \mathrm{~m}$ 以内に位置する割合が全体の $71 \%$ （全国平均：56\%）と極めて高くなっている（図－22）。これは可 住地が狭く限定されているために、残された都市部外周の狭い領域に 施設が集中して建設される傾向にあることを示している。

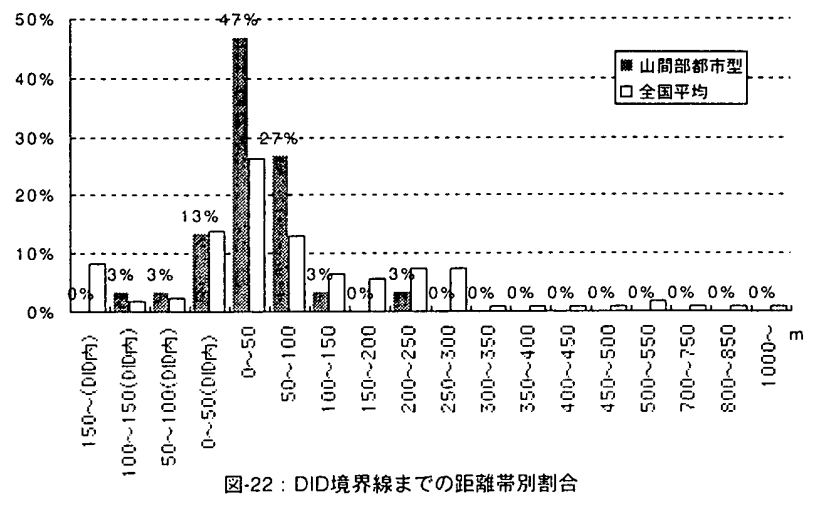




\section{（5）狭小部賑村型}

\section{基本的に「平野部農}

村型」によく似た立地 傾向を示すが、敷地の

場所の土地利用区分に ついては、林に立地す る例が $36 \%$ （全国平 均：20\%）と比較的多 く、少ない可住地を避 けて山地に設監される 㑯向を示している。

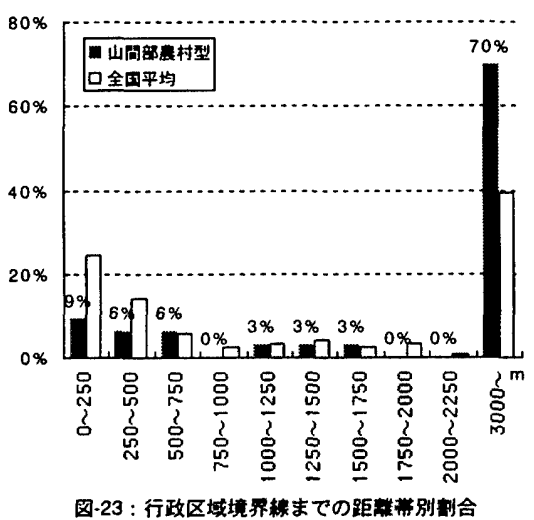

また行政区域境界線から $3 \mathrm{~km}$ 以上離れて立地する事例が全体の70\% （全国平均：39\%）を占めている（図－23）。これは平野部が比較 的少なくかつ人口も分散しているため、施設の立地による影響圈が狭 い螌囲に限られるために、特に行政区域境界線付近にまで遠ざけて設 置する要求が少ないためと考えられる。

\section{5. まとめと考察}

本調查研究では、清挦工場の立地状況について調査を行い、歴史的 経緯と全国の現状のそれぞれについて立地特性を分析し、それに影響 を与えている技術的・社会的背景の一端について把握することができ た。以下に結果を要約し、考察を加える。

\section{（1）清担工場に関する立地特性の時代変邉}

東京都区部、大阪市、京都市、神戸市の東西の 4 都市について、清 掃工場の発生から現在に至るまでの、施設配置の特性に関する時代的 な推移の調査を行った。

清掃工場の立地畩境の歴史調査からは、時代とともに配置環境は推 移しているが、一貫して各時代ごとの「郊外地」を目指して設置され る頃向にあることが明らかとなった。

\section{（2）土地利用に対する近年の立地特性}

次いで1985年〜1996年の近年11年間に新設された大規模清掃工場を 対象に、配置環境に関する全国的な調査を行った。

都市計画的な土地利用規制である地域地区区分について見ると、市 街化調整区域に設置されているケースが過半数を占めており、土地利 用区分で見ても農林地が過半を占めていることが明らかとなった。

特に「平野部都市型」の清掃事業体では、公共公益用地に設置され る例が多く、「都市+農村型」の清掃事業体では、田に立地する場合 が多いことが明らかとなった。

\section{（3）地理的条件に対する近年の立地特性}

水面との関係では、6 割の施設が水面に近接して設置され、うち半 数の施設が河川敷に近接して立地している。山地には、全体の $1 / 4$ の施設が関連して設置されていることが明らかとなった。

\section{（4）各種境界線に対する近年の立地特性}

人口の集中する地区の外縁部であるDID境界線と、社会的領域の外 縁部とみなせる清掃事業体の行政区域境界線との関係性を見ると、い ずれも境界線付近に偏在しており、全国的な傾问として、人口面で も、社会的側面でも外縁部を指向していることが明らかとなった。
特に「狭小部都市型」の清掃事業体では、7割以上の施設がDID境 界線に $100 \mathrm{~m}$ 以内で近接しており、少ない平野部の中で少しでも都市 部から離して設置しようとした結果と考えられる。

行政区域境界線に関しては、特に「平野部農村型」と「狭小部農村 型」の清抪事業体では、全国平均より距離を置いて立地する傾向にあ り、都市域が狭い範囲に限られる場合は、清㛿工場をあえて行政区域 境界線付近にまで押しやる傾向は低いと考えられる。

\section{（5）各種周辺施設に対する近年の立地特性}

公園に隣接する事例が全体の 4 割にのぼり、7割近くの事例で地域 還元施設が併設されている。周辺住民の迷惑意識対策として、公共サ 一ビス施設との併設が一般的に行われている寨状を反映していると考 えられる。その他周辺の都市施設との関倸性では、社会的に迷惑視さ れる複数の施設とまとめて設置される例が全体の 3 割に上っている。

以上、近年の大規模清掃工場における全国的傾向としては、土地利 用・地理的条件から見た「都市圈外」、人口・社会的領域から見た 「周縁部」を指向する傾向にあり、地域還元施設によって周辺住民の 迷惑意識を補僙する考え方が広く導入されている実状が示された。

\section{6. おわりに}

廃棄物の処理という、都市活動にとって重要な役割を担う清掃工場 の立地環境は、歴史的にも、近年の傾向からも、一般市民の日常生活 からは遠ざけるように選定される傾向があることが明らかとなった。

しかし、今後もさらに廃萐物の質的な多様化が進み、収集サービス が多岐に細分化されることを考感すると、輸送にかかる環境への影響 增大は避けられない。また現在の立地傾向は、ごみを排出する側の市 民に対して、排出した後のことを極力意識させない構造となってお り、環境問題を自身の問題として揵え直すにあたっては、大きな問題 を抱えていることになる。

今後の環境の時代においては、むしろ多くの市民が日常的に意識で きる都市の中枢部に清掃工場を設置し、市役所などの他の公共活動と 機能的に複合化させる (6) ことで、市民の日常生活の中に廃棄の問題 を積極的に位置づける考え方も必要となろう。

$<$ 断il: $>$

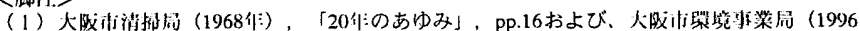

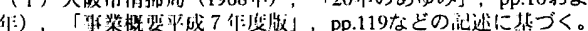

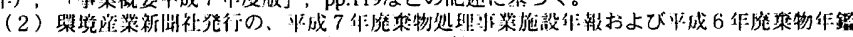

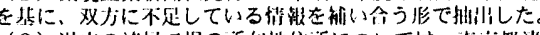

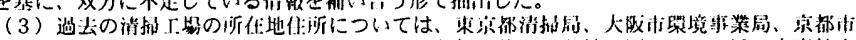

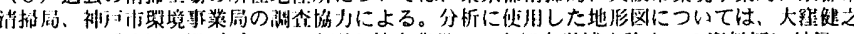

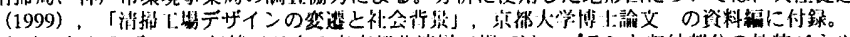

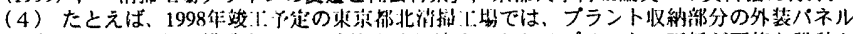

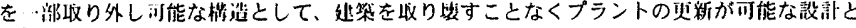
されている。

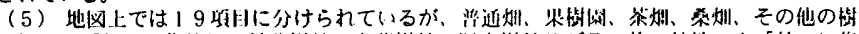

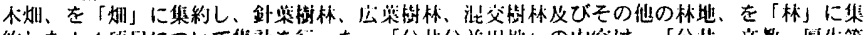

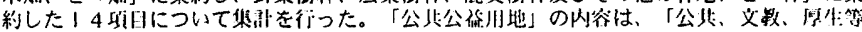

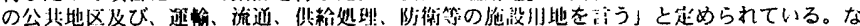

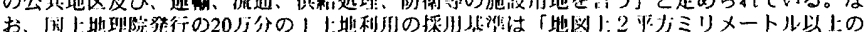

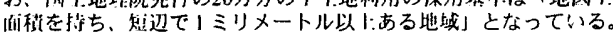

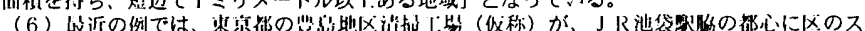

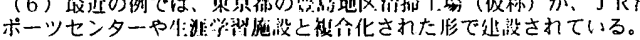

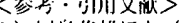

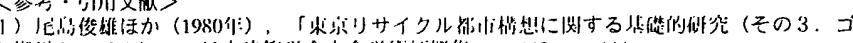

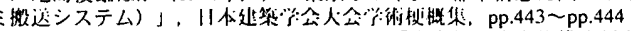

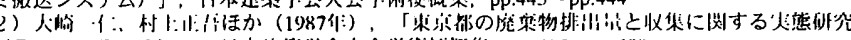

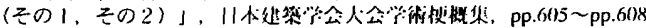

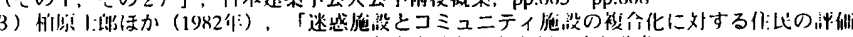

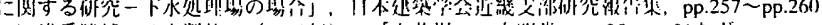

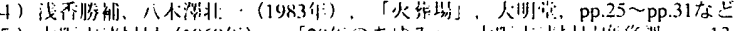

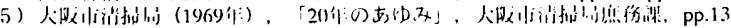

